\title{
Funding Patterns in Public Universities and Cost-Sharing In Nigeria for Global Competitiveness: Empirical Evidence from University of Calabar
}

\author{
Ada Mary Juliet", Ofem Wokasor E. \& Ameh Eyiene \\ Department of Educational Administration and Planning, University of Calabar, Leopard Town Rd, University of Calaba, Calabar, Nigeria
}

DOI: 10.36348/JAEP.2019.v03i09.004 | Received: 10.09.2019| Accepted: 17.09 .2019 | Published: 30.09 .2019

*Corresponding author: Ada Mary Juliana

\section{Abstract}

The study sought to determine funding patterns and cost-sharing in public universities in Nigeria. The main purpose of the study was to determine lecturers' perception about funding patterns and cost-sharing in public universities and provide implications for global competitiveness. To achieve the purpose, one research question and one hypothesis were developed to direct the study. One hundred (100) lecturers were purposively sampled from a population of one thousand six hundred and six (1606). A research instrument titled "Funding Patterns in Public Universities and Cost-sharing Questionnaire (FPPUCQ)" was validated, and administered to twenty (20) lecturers, for data collection. Data collected were analyzed with Mean, Standard Deviation and Independent t-test. The result showed that funding patterns and costsharing need improvement. It was concluded that the funding patterns and cost-sharing in universities needs improvement in order to ensure the provision of quality education for global competitiveness. It was recommended among others that managers of universities should be more prudent in utilizing the meager allocations of government, students' contribution, internally generated revenue, philanthropic donations, among others.

Keywords: Funding, Cost-sharing, University, Global Competitiveness.

Copyright @ 2019: This is an open-access article distributed under the terms of the Creative Commons Attribution license which permits unrestricted use, distribution, and reproduction in any medium for non-commercial use (NonCommercial, or CC-BY-NC) provided the original author and sources are credited.

\section{INTRODUCTION}

Education is adjudged to be a stimulant for improving socioeconomic, political and cultural development of a nation. As a game changer, its importance in the overall transformation of an individual and contribution to national development cannot be overstated. Nigeria's educational system is categorized into three levels-primary, secondary and tertiary, with the university occupying the top in the echelon of higher education. University education is the pinnacle of higher education where human capital that is capable of competing globally are trained and developed for societal transformation. Globally, university education is the most prestigious, much sought after and perceived to be the breeding ground in filling the gap of critical manpower needs of nations. These characteristics have placed Nigeria's university education in the trajectory of increased number from 6 (six) between 1960 and 1970 to 153 (one hundred and fifty three) in 2017 [1]. The above scenario indicates a 2.7 percent average increase in the number of universities which portend increased running cost for management. This increase hit a point where government openly acknowledged that it can no longer saddle the responsibility of funding education alone [2].

As a developing nation, Nigeria's education ab initio has witnessed inadequate funding and non compliance to UNESCO's recommendation for developing nations to allocate 26 percent of their annual budgetary provision to the sector. This situation has left universities in a state of advanced decay with most teaching staff leaving the country in droves in search of greener pasture abroad [2]. Additionally, enrolment by students of low parents' socioeconomic status has been on the decline owing to increased cost and demand for university education as well as government's debilitating funding pattern leading to poor quality output. The highest percentage ever allocated to the sector was 17.59 in 1997. From 1999 to 2018, the highest allocated percentage is 11.12 in 1999 with the lowest being 1.83 in 2003. A comparative analysis of education funding among developing nations indicate that in 2012, Nigeria allocated 8.4 percent compared to Ghana 31.0 percent, Cote d Iviore 30.0 percent, Uganda 27.0 percent, Morocco 26.4 percent etc [3]. 
In Nigeria, anxieties in education are stirred by the combined effects of population explosion in the classrooms at all levels, deteriorating facilities, continued inadequacy of funding, recurrent strike actions leading to truncated academic calendar particularly in higher institutions [4]. It is therefore, more apt to address the issue of quality university education as outcome of adequate funding. According to Igbeneweka and Enowoghomwenma [5], quality education refers to the suitability of the education system in relation to its goals and objectives. It has to do with issues of relevance, validity, functionalism and efficiency in the attainment of prescribed goals and objectives of the educational system. University education can only attain the above status when adequately funded. Quality education entails good learning environment, relevant curricular, effective teaching-learning process and good learning outcome. The opposite of the above according to Agabi [6], leads to poor job performance, poor quality graduate who may not be able to compete globally, the incidence of brain drain of the best teaching and administrative personnel out of the university to other sectors of the economy or out rightly to other countries in search of better working environment.

It is an undebatable axiom that education is a social service whose cost is cumbersome. This position is corroborated by Federal Republic of Nigeria [7], recognizing education as an expensive social service that requires adequate financial provision for the successful implementation of educational programmes. In order to produce gradautes who can globally compete with their contemporaries, university management need funds to pay salaries of all catergory of employees, procure instructional resources and equipment for classrooms, furnish staff offices, build infrastructure, improve academic research and development, cater for the contemporary students' enrolment explosion and to complement the multifaceted services needed. With the avalanche of areas for finacial expenditure which is difficult to be borne by the proprietor alone, federal government decided through the National Universities Commission to make it mandatory for all public iniversities to generate 10 percent of their total yearly funds internally through various diversification means [8].

While emphasizing the importance of university education, Ekundayo and Ajayi [9] averred that the funds allocated to higher education should not merely be considered as an expense but a long-term investment that could yield benefit to society as a whole. These benefits are reflected in the socioeconomic outlook of citizens in terms of better healthcare, lower unemployment rate, lower crime rate, increased political awareness and participation, higher tax returns, among other indirect benefits. It is on this premise that funding university education by stakeholders is a necessary condition for the enhancement of the aforementioned benefits. In view of this, Hartnett [10] cited in Ogunyinka [11] suggested that more creative and adaptative strategies are needed in order for Nigerian universities to offset the declining educational quality, resource use efficiency and learning effectiveness that now confronts them. Nigerian universites adopted an array of cost-sharing measures as shown eventually in this paper.

Ofoegbu and Alonge [12] examined internally generated revenue and effectiveness of university administration in Nigeria. They found out that commerial ventures were among the main sources of IGR while the proceeds were used for services including staff welfare, maintenance of facilities and beautification of the university premises. Their result also revealed a significant relationship between internally generated revenue and the management of universities in Southern Nigeria. They recommended that university administrators should be more transformative in their leadership style in order to strengthen their revenue base for effectiveness in university management.

Igbineweka and Enowoghomwenma [5] investigated internally generated revenue suitablity and quality assurance in some Nigerian universities. The results of analysis showed that the level of IGR suitability in financing university education is low. The extent to which IGR contributes to quality assurance in university education was also found to be very low. They recommended that government should adequately provide funds for the universities in addition to allowing universities charge appropriate and reasonable tuition fees.

As the conversation on funding university education ensues, it becomes very pertinent to bring to the fore the concept of cost-sharing. Cost-sharing in higher education generally refers to a shift in the burden of higher education costs from its being borne exclusively by government, or taxpayers, to it being shared with students and/or their parents. Maliyamkono and Ogbu [13] define it as the introduction of shared responsibilities of education expenses between the government and the beneficiaries, who are the students and their families. More specifically, it is so defined as the introduction of, or especially sharp increases in tuition to cover part of the costs of instruction or of user charges to cover more of the costs of lodging, food, and other expenses of student living that may hitherto been borne substantially by governments (taxpayers) or institutions [14].

Cost-sharing in higher education can take different forms. Examples are: the introduction of tuition fees where they previously did not exist, a steep rise in tuition fees where they are already in existence, or public higher education institutions charging more or nearly break-even or full cost fees for accommodation, 
Ada Mary Juliet et al; J Adv Educ Philos, Sep 2019; 3(9): 330-334

board, books and other ancillary costs that may hitherto have been borne by government [14]. It may also take the form of a reduction, or even the abolition of student grants [15].

Undergraduate students across academic programmes and faculties who share part of their cost of education pay very low school charges thus making internally generated revenue from school charges cooperatively insignificant against what is paid in developed economies of the world where full-time students contribute as much as 80 percent of universities' internally generated revenues (See Table$1)$.

\begin{tabular}{|c|c|}
\hline \multirow{2}{*}{\multicolumn{2}{|c|}{$\begin{array}{l}\text { Table-1: University of Calabar, Cross River } \\
\text { fresh undergraduates school charges }\end{array}$}} \\
\hline & \\
\hline Fee charges & Amount (N) \\
\hline Development levy & 10,000 \\
\hline Library & 1,000 \\
\hline Security & 1,200 \\
\hline Medical referral & 500 \\
\hline Medical fee & 800 \\
\hline Medical exams & 1,500 \\
\hline Mb.Bch. students & 5,000 \\
\hline Other students & 2,000 \\
\hline General rehabilitation & 2,000 \\
\hline Acceptance fee & 2,500 \\
\hline Endowment fee & 1,000 \\
\hline Unity fee & 2,000 \\
\hline Database fund & 2,000 \\
\hline ICT training & 5,000 \\
\hline Result verification & 1,250 \\
\hline Sanitation & 1,000 \\
\hline Science students & 1,500 \\
\hline Non-science students & 1,000 \\
\hline Games & $\mathrm{I}, 500$ \\
\hline ID card & 500 \\
\hline Screening & 750 \\
\hline Caution fee & 500 \\
\hline SUG & 500 \\
\hline Students welfare & 1,000 \\
\hline Students Affairs & 300 \\
\hline Students handbook & 300 \\
\hline NYAP & 200 \\
\hline Total & 46,800 \\
\hline
\end{tabular}

Source: Unical 2014 e-portal

According to Igbeneweka and Enowoghomwenma [5], this situation is counterproductive because government's budgetary allocation to universities have been inadequate in addition to reluctance to allow univesity authorities charge appropriate and reasonable school fees. Another component for revenue generation for university management according to Hinchliffe [16], is the Education Tax Fund financed by a two (2) percent levy on pre-tax earnings of firms with more than 100 employees; half of these funds are earmarked for higher education which is still infinitesimally small.

In recent times, due to dwindling oil revenue coupled with increased demand for education, government is no longer able to fund university education alone. This necessitated the need for cost of funding to be shared among stakeholders who include: parents, students, philanthropist, government, corporate organizations among others. This development does not go well with students/parents as the cost-sharing has no clear-cut metrics resulting in disproportionate sharing. Families of low socio-economic status are constrained sending their children to university for choice academic discipline owing to high cost of tuition and other charges. This unfortunate situation is unacceptable taking into account the importance of university education in a developing nation like Nigeria, hence the need for this study.

\section{Purpose of the Study}

The main purpose of this study was to determine lecturers' perception about funding patterns and cost-sharing in university education and to provide implication for global competitiveness. Specifically, this study sought to:

- Determine lecturers' perception about funding patterns and cost-sharing among university stakeholders.

- Examine the difference in the perception of male and female lecturers on funding and costsharing patterns in universities.

\section{Research Question}

1. What are lecturers' perceptions on funding patterns and cost-sharing in universities?

\section{Statement of Hypothesis}

1. There is no significant difference in the mean ratings of male and female lecturers on funding patterns and cost sharing in universities.

\section{RESEARCH METHODOLOGY}

The study adopted survey research design. One hundred (100) lecturers (73 males and 27 females) were purposively selected from a population of 1606 in the University of Calabar for the study. A validated researcher-made questionnaire titled "Funding Patterns in Public Universities and Cost-sharing Questionnaire (FPPUCQ)" was used for data collection. The instrument had a four-point rating scale of Improvement Highly Needed (IHN), Improvement Needed (IN), Improvement Slightly Needed (ISN) and Improvement Not Needed (INN) with corresponding scores of 4, 3, 2, and 1 respectively. A reliability index of 0.78 was achieved for the instrument using Cronbach Alpha reliability estimate. Twenty (20) respondents were used for the trial test that did not form part of the main study. 
The researchers administered the instrument to the respondents in the study area and at the end of the exercise, 100 percent return rate was obtained. Data collected were analyzed using Mean and Standard Deviation in answering the research question while Independent t-test was used in answering the null hypothesis at .05 level of significance and 98 degree of freedom. The following decisions guided the interpretation of analysis made:

- A cut-off point of 2.50 was used in answering the research question. This implied that improvement is needed in funding patterns and cost-sharing by the lecturer for any item whose mean is $\geq 2.50$ and improvement is not needed for any item whose mean is $\leq 2.50$.

- The hypothesis of no significant difference (Ho) was upheld for any item whose tcalculated value is $\leq$ the t-table value of 1.98 at probability of .05 level of significance and 98 degree of freedom.

\section{RESULT}

Research question 1: What are lecturers' perception on funding patterns and cost-sharing in universities? This research question was answered using mean and standard deviation as presented in Table-2.

Table-2: Mean and standard deviation for the responses of lecturers' on funding patterns and cost sharing in universities $N=100$

\begin{tabular}{|c|c|c|c|c|}
\hline $\mathbf{S} / \mathbf{N}$ & Items & $\bar{X}$ & SD & $\mathbf{R M}$ \\
\hline 1 & School charges are adequate for the provision of learning materials. & 2.61 & 0.85 & IN \\
\hline 2 & Government should abolish the non-tuition policy. & 2.81 & 0.81 & IN \\
\hline 3 & The funding of education should be solely the duty of government. & 3.17 & 0.65 & IN \\
\hline 4 & Philanthropists should be made to contribute more to funding of education. & 3.02 & 0.71 & IN \\
\hline 5 & Education Tax Fund of $2 \%$ levy on pre-tax earnings of firms should be reviewed upward. & 2.99 & 0.77 & IN \\
\hline 6 & Universities should make effort to improve internally generated revenue. & 3.03 & 0.66 & IN \\
\hline 7 & Private individuals should be encouraged to Build, Operate and Transfer hostels to universities. & 2.30 & 0.76 & IHN \\
\hline
\end{tabular}

Results in Table- 2 revealed that six (6) items recorded mean ratings between 2.61 and 3.03 which were above 2.50 cut-off point on the four points scale. The result shows that the six (6) funding patterns and cost sharing need improvement while the last item need high improvement. The standard deviation ranged from 0.65 to 0.85 which revealed that respondents were not far from the mean of each other in their responses.

\section{Hypothesis one}

There is no significant difference in the mean ratings of male and female lecturers on funding patterns and cost sharing in universities. This hypothesis was tested using independent t-test analysis as presented in Table-3.

Table-3: Independent-test analysis to compare the mean ratings of male and female lecturers on funding pattern

and cost-sharing in universities $(\mathbf{N}=\mathbf{1 0 0})$
\begin{tabular}{|l|l|l|l|l|}
\hline Variable & N & $\mathbf{X}$ & SD & t-cal \\
\hline Male & 73 & 22.178 & 3.831 & \\
Female & 27 & 20.666 & 3.648 & 1.774 \\
\hline
\end{tabular}
Significant at .05 , critical t-value $=1.984, \mathrm{df}=98$

Results from Table- 3 revealed that the calculated t-value of 1.774 was lesser than the critical tvalue of 1.984 at .05 level significance. Thus, the null hypothesis was rejected. This implies that male and female lecturers disagreed on the funding patterns and cost-sharing in universities.

\section{DISCUSSION OF FINDINGS}

It was found that funding patterns and costsharing among the various stakeholders in education need some level of improvement in order to make funds available for university management in the provision of quality education. This, by extension could lead to the production of quality university graduates who would compete globally with their peers from other parts of the world. The finding of this study is in consonance with that of Ofoegbu and Alonge [12] who opined that proceeds from internally generated revenue were used for services including staff welfare, maintenance of facilities and beautification of the university premises.

However, it is common knowledge that universities in Nigeria have not enjoyed the financial resources necessary to maintain educational quality in the midst of significant enrolment explosion. Thus, cost-sharing is necessary due to the fact that the gross under-funding of the education sector has the capability of rendering the university system incapacitated. Low morale among lecturers, poor and inadequate instructional materials, poor research and development grants to lecturers, inadequate office space for university staff, incessant strike actions, among others, are some of the indicators of inadequate funding of universities in Nigeria.

For the above reasons, Igbineweka and Enowoghomwenma [5] advanced that government should adequately provide funds for the universities in addition to allowing universities charge appropriate and reasonable tuition fees. This could be due to the fact that funding of education especially at the university level cannot not be left in the hands of government alone if quality eduaction is desired by the society. 
Ada Mary Juliet et al; J Adv Educ Philos, Sep 2019; 3(9): 330-334

\section{CONCLUSION}

Based on the results of the study, it was concluded that the funding patterns and cost-sharing in universities need improvement to ensure the provision of quality education for global competitiveness.

\section{Implication for Global Competitiveness}

For the fact that all the items that measured lecturers' perception of funding patterns and costsharing in universities recorded "improvement needed" and "improvement highly needed" implies that adequate funding and cost-sharing are factors to be considered by university management if universities in Nigeria will be qualitative for global competitiveness. Policy makers should therefore integrate adequacy of funding and cost-sharing factors in university management policy framework. To do this, the Federal Ministry of Education through the National Universities Commission (NUC) should streamline the stakeholders that will be involved in the cost-sharing with clear-cut metrics and ratio of sharing among them.

\section{RECOMMENDATIONS}

Based on the conclusion of this study, the following recommendations were made:

- Parents and students must know that cost of getting high quality education is not cheap because the ability to pay fees will guarantee that universities become liable to them. Thus, government's policy on non-tuition should be revisited/ reviewed.

- Managers of universities should be more prudent in utilizing the meager allocations of government, students' contribution, internally generated revenue, philanthropic donations and others.

- Staff welfare and working conditions should be given adequate consideration in order to foster quality education that will enhance graduates' global competitiveness.

- All stakeholders in education, especially the private sector, should be encouraged to share in the burden of funding education because, in the long run, graduates from universities will serve the manpower needs of the private sector.

\section{REFERENCES}

1. Ogbonnaya, O. (2017). List of approved universities in Nigeria. NationalUniversities Commission Monday 16 October Bulletin, 18-19.

2. Oraka, A. O., Ogbodo, C. Y., \& Ezejiofor, R. A. (2017). Effect of Tertiary Education Tax Fund (Tetfund) in Management of Nigeria Teriary Institutions. International Journal of Trend in Scientific Research and Developmen (IJTSRD) International Open Access Journal, 2(1), 140-150.

3. Matthew, I. A. (2016). Financial allocation to education: Trends, issues and way forward. Journal Plus Education, 227-242.
4. Ojedele, P. K., Oyekan. O. A., \& Jeremiah, N. D. (2016). Quality control in higher education: A neccessity in Nigeria. International Journal of Educational Administration Planning and Research, 7(2), 249-258.

5. Igbineweka, V. O., \& Enowoghomwenma, D. E. (2017). Internally generated revenue (IGR) suitability and quality assurance in some Nigerian universities. International Journal of Educational Benchmark (IJEB), 7(2), 116-124.

6. Agabi, O. G. (2007). Sharing the cost of educational investment in less developing countries: A socioeconomic rationalty option. Journal of Education in Developing Areas, 11, 4962.

7. Federal Republic of Nigeria. (2008). NationalPolicy on Education. Lagos: Nigerian Education Research Development Council.

8. Muhammad, U., \& Aliyu, U. A. (2017). Funding as a tool for revitalizing university education for social political and economic engineering in Nigeria. International Journal of Topical Educational Issues, 1(2), 269-282.

9. Ekundayo, H. T., \& Ajayi, I. A. (2009). Towards effective management of university education in Nigeria. International NGO Journal, 4(8), 342347.

10. Hartnett, M. E., Stratton, R. D., Browne, R. W., Rosner, B. A., Lanham, R. J., \& Armstrong, D. O. N. A. L. D. (2000). Serum markers of oxidative stress and severity of diabetic retinopathy. Diabetes care, 23(2), 234-240.

11. Ogunyinka, E. K. (2013). Higher ducation funding and cost sharing: Case study of Universities in Nigeria. Academic Research Internatiional, 521535.

12. Ofoegbu, F. I. \& Alonge, H. O. (2016). Internally generated revenue and effectiveness of university administration in Nigeria. Journal of Education and Practice. 5(2), 1-8.

13. Maliyamkono, T. L., \& Ogbu, O. (1999). CostSharing in Education and Health: Perspectives from East and Southern Africa. Dare-es-Salaam: Tema PublishersTema Publishers.

14. Johnstone, D. B. (2003). Cost-sharing in higher education: Tuition, financial assistance, and accessibility in a comparative perspective. Journal of Czech Sociological Review, 39(3), 351-374.

15. Johnstone, D. B. (2006). Financing higher education: "Cost-sharing in International Perspective". In Altbach. P. G. (ed.) Global Perspective on Higher Education. Boston: College Centre for International Higher Education.

16. Hinchliffe, K. (2002). Public expenditure in education in Nigeria: Issues, estimates and some implications. Abuja: World Bank. 